\title{
Therapeutic effects of $\beta$-elemene via attenuation of the Wnt/ $\beta$-catenin signaling pathway in cervical cancer cells
}

\author{
LUFANG WANG $^{1}$, YANYAN ZHAO ${ }^{1}$, QIONG WU $^{1}$, YIFU GUAN ${ }^{2}$ and XIN WU ${ }^{1}$ \\ ${ }^{1}$ Department of Gynecology, The First Affiliated Hospital of China Medical University; \\ ${ }^{2}$ Department of Biochemistry and Molecular Biology, China Medical University, Shenyang, Liaoning 110000, P.R. China
}

Received March 23, 2017; Accepted December 12, 2017

DOI: $10.3892 / \mathrm{mmr} .2018 .8455$

\begin{abstract}
Concurrent radio chemotherapy treatment prolongs the survival rate of patients with advanced cervical cancer; however, it has adverse side-effects. $\beta$-elemene, an active component of the traditional Chinese medicinal herb Curcuma zedoaria, is a promising alternative therapeutic drug for the treatment of advanced cervical cancer. The aim of the present study was to investigate the antitumor effects of $\beta$-elemene in human cervical cancer SiHa cells and to determine its underlying therapeutic molecular mechanisms. Cell viability, cell cycle progression and apoptosis were detected using an MTT assay and flow cytometry analysis. Furthermore, the levels of cell migration and cell invasion were investigated using Transwell and wound healing assays. The expression levels of Cyclin-dependent kinase inhibitor 2B (P15), Cyclin D1, cellular tumor antigen p53, apoptosis regulator $\mathrm{Bcl}-2$ (Bcl-2), apoptosis regulator $\mathrm{BAX}$ (Bax), $72 \mathrm{kDa}$ type IV collagenase (MMP-2), matrix metalloproteinase-9 (MMP-9), $\beta$-catenin, transcription factor 7 (TCF7), and Myc proto-oncogene protein (c-Myc) were analyzed via western blotting. The results revealed that $\beta$-elemene inhibited the proliferation of SiHa cells in a dose and time-dependent manner. Administration of $\beta$-elemene induced G1 phase cell-cycle arrest, as demonstrated by the upregulation of P15 expression and the downregulation of Cyclin D1 expression. Furthermore, the present study revealed that $\beta$-elemene induced apoptosis in $\mathrm{SiHa}$ cells by enhancing the expression of $\mathrm{p} 53$ and Bax, and suppressing the expression of Bcl-2. In addition, treatment with $\beta$-elemene inhibited cell migration and invasion via downregulation of MMP-2 and MMP-9 expression levels. Western blotting demonstrated that $\beta$-elemene reduced the expression levels
\end{abstract}

Correspondence to: Dr Xin Wu, Department of Gynecology, The First Affiliated Hospital of China Medical University, 155 Nanjing North Road, Shenyang, Liaoning 110000, P.R. China

E-mail: xinwu.1964@aliyun.com

Key words: $\beta$-elemene, apoptosis, proliferation, invasion, cervical cancer, Wnt $/ \beta$-catenin of $\beta$-catenin and its downstream target molecule TCF7, thus resulting in reduced levels of their target proteins, including c-Myc, Cyclin D1, Bax and MMP-2 in cervical cancer cells. The results of the present study suggested that $\beta$-elemene may inhibit cell proliferation and invasion, in addition to inducing apoptosis, via attenuation of the $\mathrm{Wnt} / \beta$-catenin signaling pathway in cervical cancer cells.

\section{Introduction}

Cervical cancer is the second most prominent type of malignant tumor affecting women and the second leading cause of cancer mortality affecting females in China (1). Primary treatments for cervical cancer include surgery (including pelvic lymphadenectomy and radical hysterectomy), radiotherapy and chemotherapy. Radical hysterectomy and radiotherapy are considered to be curative for localized disease; whereas, for the treatment of advanced stage cancer, concurrent radiochemotherapy remains a cornerstone intervention. However, increasing systemic toxicity caused by radiochemotherapy, lack of tumor control, recurrence and metastasis significantly reduce the survival rate of advanced cervical cancer (2). Chemotherapy, despite continuing to be the most common auxiliary treatment and palliative care option for recurrent and metastatic cancer, results in unfavorable prognoses and frequently causes an increase in systemic toxicity and chemoresistance. Thus, there is a requirement for the development of novel antitumor reagents for the treatment of recurrent and metastatic cervical cancers. Currently, despite investigations into the development of alternative adjuvant treatment methods, including molecular targeted therapy and immunotherapy, the majority of research remains at the exploratory stage, and only anti-vascular endothelial growth factor has been used for the clinical treatment of cervical cancer (3). Traditional Chinese medicine has long been used to treat tumors and its anti-tumor role has received increased research attention (4).

Curcuma zedoaria, also known as Rhizoma zedoariae, belongs to the Zingiberaceae family and has been used widely to treat cervical lesions since the early 1940s (5). Furthermore, zedoary turmeric oil has previously been used in clinical practice for the treatment of cervical inflammation and human papilloma virus infection in China (6). Elemene, a component of Rhizoma zedoariae oil, may take the form of $\alpha, \beta, \delta$ and $\gamma$-elemene. $\beta$-elemene is the main active component of 
Rhizoma zedoariae oil and has been revealed to demonstrate antitumor effects in various cancers, including glioma, laryngeal cancer, leukemia and ovarian cancer (7-9). Despite certain studies discussing the therapeutic mechanisms of $\beta$-elemene with regards to cancer $(10,11)$, the underlying molecular mechanisms of $\beta$-elemene have not yet been determined. In addition, the role of $\beta$-elemene in cervical cancer cells has not been widely studied. Wnt/ $\beta$-catenin signaling participates in the processes of embryogenesis and is additionally active in adult organisms. The upregulation of a number of $\mathrm{Wnt} / \beta$-catenin signaling pathway members is closely associated with certain cancer types. Overexpression of $\beta$-catenin has previously been detected in various cancers, such as intestinal cancer and ovarian carcinomas (12). Furthermore, Wnt/ $\beta$-catenin signaling is an essential pathway for the modulation of the proliferation, differentiation and motility of cells (13). The present study aimed to investigate whether $\beta$-elemene was able to inhibit cell proliferation, promote cellular apoptosis and decrease the invasive properties of cervical cancer cells, and to determine whether these effects occur as a result of the functioning of the $\mathrm{Wnt} / \beta$-catenin signaling pathway.

\section{Materials and methods}

Chemicals and reagents. SiHa cells were obtained from the American Type Culture Collection (Manassas, VA, USA). $\beta$-elemene was obtained from Dalian Huali JinGang Pharmaceutical Co., Ltd. (Dalian, China) and dissolved in PBS in order to generate a $5 \mathrm{mg} / \mathrm{ml}$ stock solution for experimental use. In addition, MTT was purchased from Beijing Huaxia Ocean Science and Technology Co., Ltd. (Beijing, China). Dulbecco's modified Eagle's medium (DMEM), fetal bovine serum (FBS), PBS and trypsin/EDTA solution were purchased (Gibco; Thermo Fisher Scientific Inc., Waltham, MA, USA). Matrigel was purchased from BD Biosciences (Franklin Lakes, NJ, USA). A bicinchoninic acid (BCA) protein assay kit, in addition to cell cycle and apoptosis analysis kits, was purchased from Nanjing KeyGen Biotech. Co., Ltd. (Nanjing, China).Primary antibodies against Cyclin-dependent kinase inhibitor 2B (P15) (cat. no. AB33457), Cyclin D1 (cat. no. AB12597), P53 (cat. no. AB41876), apoptosis regulator Bcl-2 (Bcl-2) (cat. no. AB40639), apoptosis regulator BAX (Bax) (cat. no. AB40636), $\beta$-catenin (cat. no. AB40439), Myc proto-oncogene protein (c-Myc)(cat.no.AB40766)and GAPDH (cat. no. AB21612), and the secondary horseradish peroxidase (HRP)-conjugated goat anti-rabbit-IgG (cat. no. ABL3012-2) and HRP-conjugated goat anti-mouse-IgG antibodies (cat. no. ABL3031-2), were purchased from Bioscience Technology, Inc. (www.abscitech.com/; College Park, MD, USA). The primary antibodies against transcription factor 7 (TCF7; cat. no. 14464-1-AP), 72 kDa type IV collagenase (MMP-2; cat. no. 10373-2-AP) and matrix metalloproteinase-9 (MMP-9; cat. no. 10375-2-AP) were purchased from ProteinTech Group, Inc. (Chicago,IL,USA). Both the primary and secondary antibodies were diluted to $1: 1,000$.

Cell cultures. SiHa cells were cultured in DMEM containing $10 \%$ FBS and placed in an incubator with a saturated, humidified atmosphere with $5 \% \mathrm{CO}_{2}$ at $37^{\circ} \mathrm{C}$. Logarithmically growing cells were used in All Subsequent Experiments.
Cell proliferation assay. The MTT assay was used in order to evaluate the proliferation of $\mathrm{SiHa}$ cells. SiHa cells were seeded into 96-well microtiter plates at $5 \times 10^{3}$ cells/well and treated with increasing concentrations of $\beta$-elemene $(0-50 \mu \mathrm{g} / \mathrm{ml})$ for 24, 48 and $72 \mathrm{~h}$. Following this, $20 \mu \mathrm{l}$ MTT solution was added to each well and incubation continued at $37^{\circ} \mathrm{C}$ for further $4 \mathrm{~h}$. Dimethyl sulfoxide $(150 \mu \mathrm{l})$ was added to each well and incubation was continued at room temperature for $20 \mathrm{~min}$. The optical density value of each well was detected at a wavelength of $490 \mathrm{~nm}$. Each assay was performed in triplicate.

Flow cytometry analysis of the cell cycle and apoptosis. SiHa cells $\left(1 \times 10^{6}\right)$ were exposed to different concentrations of $\beta$-elemene $(0,20,30$ and $40 \mu \mathrm{g} / \mathrm{ml})$ for $48 \mathrm{~h}$ and harvested. The cell cycle was investigated using a Cell Cycle Detection kit (Nanjing KeyGen Biotech Co., Ltd., Nanjing, China). Briefly, SiHa cells were washed with PBS and then fixed with $70 \%$ ethanol at $4^{\circ} \mathrm{C}$ for $30 \mathrm{~min}$. Following this, the cells were suspended in $300 \mu \mathrm{l}$ PBS and incubated with propidium iodide (PI; $20 \mathrm{mg} / \mathrm{ml}$ ) and RNase $(1 \mathrm{mg} / \mathrm{ml}$ ) for $30 \mathrm{~min}$. Cellular DNA was stained with propidium iodide (Nanjing KeyGen Biotech Co., Ltd.). Cell cycle distributions were determined by flow cytometry using a BD FACSCalibur system (BD Biosciences) and data was analyzed using the ModFit software version 4.1 (Verity Software House, Inc., Topsham, ME, USA). An Annexin V-FITC Apoptosis Detection kit (Nanjing KeyGen Biotech Co., Ltd.) was used to investigate cellular apoptosis. SiHa cells were washed with PBS and resuspended in $500 \mu 1$ binding buffer. Annexin V-fluorescein isothiocyanate $(5 \mu \mathrm{l})$ and PI (5 $\mu \mathrm{l})$ were added to the samples, according to the manufacturer's protocol. Finally, the processed cells were subjected to flow cytometry and data were analyzed using the Cell Quest software version 5.1 (BD Biosciences). Each experiment was performed in triplicate.

Transwell assay. In preparation for the motility assay, $\mathrm{SiHa}$ cells were resuspended at a density of $1 \times 10^{5}$ cells $/ \mathrm{ml}$ in serum-free DMEM. The cell suspension $(200 \mu \mathrm{l})$ was added to different concentrations of $\beta$-elemene $(0,20,30$ and $40 \mu \mathrm{g} / \mathrm{ml})$ and placed in an upper Transwell chamber (BD Biosciences). Simultaneously, $600 \mu \mathrm{l}$ conditioned medium containing $20 \%$ FBS, in addition to the different aforementioned concentrations of $\beta$-elemene, was added to the bottom Transwell chamber. Following a further $24 \mathrm{~h}$ incubation period at $37^{\circ} \mathrm{C}$, the $\mathrm{SiHa}$ cells that had migrated to the bottom chamber were fixed in methanol for $30 \mathrm{~min}$ at room temperature, stained with crystal violet for $30 \mathrm{~min}$ at room temperature, and counted using a light microscope under a 10 -fold mirror vision. In order to perform the invasion assay, $40 \mu 1$ Matrigel $(0.5 \mathrm{mg} / \mathrm{ml}$; Beckman Coulter, Inc., Brea, CA, USA) was spread onto the upper Transwell chamber and incubated for $4 \mathrm{~h}$ at $37^{\circ} \mathrm{C}$. The plating of the lower chamber was performed in accordance with the aforementioned protocol. Following this, the cells were incubated for $72 \mathrm{~h}$ at $37^{\circ} \mathrm{C}$ in the Transwell device and then fixed, stained and counted according to the aforementioned protocol. Each assay was performed in triplicate.

Wound healing assay. SiHa cells at a density of $1 \times 10^{5}$ cells/well in medium containing $10 \%$ FBS were plated into a 6 -well plate and incubated for $24 \mathrm{~h}\left(37^{\circ} \mathrm{C}, 5 \% \mathrm{CO}_{2}\right)$ until the cell monolayer 
covered the plate. A sterile $200 \mu \mathrm{l}$ plastic pipette tip was used to scratch vertically on the cell layer in order to make a wound. Following this, the cells were incubated for $48 \mathrm{~h}\left(37^{\circ} \mathrm{C}\right.$, $\left.5 \% \mathrm{CO}_{2}\right)$ with different concentrations of $\beta$-elemene $(0,20,30$ and $40 \mu \mathrm{g} / \mathrm{ml}$ ) under serum-free conditions. The gap distance was measured at 0 and $48 \mathrm{~h}$ using a light microscope under a 4-fold mirror vision. Each assay was conducted in triplicate.

Preparation of proteins and western blot analysis. Following treatment of SiHa cells with $\beta$-elemene $(40 \mu \mathrm{g} / \mathrm{ml})$ for $48 \mathrm{~h}$, radioimmunoprecipitation assay buffer (cat. no. WLA014a; Wanlei Life Science, Shenyang, China) containing phenylmethylsulfonyl fluoride was added in order to extract the total protein. A BCA assay kit (Nanjing KeyGen Biotech. Co., Ltd.) was used to measure the protein concentration. Equal amounts of protein $(60 \mu \mathrm{g})$ were separated by SDS-PAGE on a $10 \%$ gel and transferred onto polyvinylidene difluoride membranes. The membranes were blocked using 5\% skimmed milk at room temperature for $2 \mathrm{~h}$ and incubated with appropriate primary antibodies against P15, Cyclin D1, p53, Bcl-2, Bax, $\beta$-catenin, c-Myc, TCF7, MMP-2, MMP-9 and GAPDH at $4^{\circ} \mathrm{C}$ overnight. Following this, the membranes were incubated with the secondary antibodies (anti-rabbit or anti-mouse) for $1 \mathrm{~h}$ at $37^{\circ} \mathrm{C}$. Finally, the immune reactive proteins were detected using an enhanced chemiluminescence kit (cat. no. WLA003a; Wanlei Life Science). Protein bands were quantified using Quantity One software (version 4.6.3; BioRad Laboratories, Inc.) and normalized against GAPDH. Each experiment was performed in triplicate.

Statistical analysis. SPSS software (version 17.1; SPSS, Inc., Chicago, IL, USA) was used to analyze the statistical data, and the data are presented as the mean \pm standard deviation. The Student's t-test was used to evaluate the differences between the control group and the experimental group, and one-way analysis of variance followed by Tukey's test was used to evaluate the differences among multiple groups. $\mathrm{P}<0.05$ was considered to indicate a statistically significant difference.

\section{Results}

$\beta$-elemene inhibits the proliferation and survival of SiHa cells. The results of the MTT assay revealed that $\beta$-elemene reduced the viability of SiHa cells in a dose and time-dependent manner, and the half-maximal inhibitory concentration values of $\beta$-elemene for SiHa cells were 42.17, 29.20 and $21.29 \mu \mathrm{g} / \mathrm{ml}$ at 24,48 and $72 \mathrm{~h}$, respectively $(\mathrm{P}<0.05$; Fig. 1$)$.

$\beta$-elemene induces cell-cycle arrest at the G1 phase in SiHa cells. Cell cycle analysis demonstrated that following treatment with increasing doses of $\beta$-elemene $(20,30$ and $40 \mu \mathrm{g} / \mathrm{ml})$, the number of SiHa cells arrested at the G1 phase of the cell cycle significantly increased compared with $0 \mu \mathrm{g} / \mathrm{ml}(\mathrm{P}<0.05$; Fig. 2A), which suggested that the administration of $\beta$-elemene arrested SiHa cells at the G1 phase by reducing their ability to divide and inhibiting their proliferation. Furthermore, cell cycle-associated proteins were investigated, and it was revealed that the administration of $\beta$-elemene upregulated the expression of P15 and downregulated the expression of Cyclin D1 ( $\mathrm{P}<0.05$; Fig. 2B).

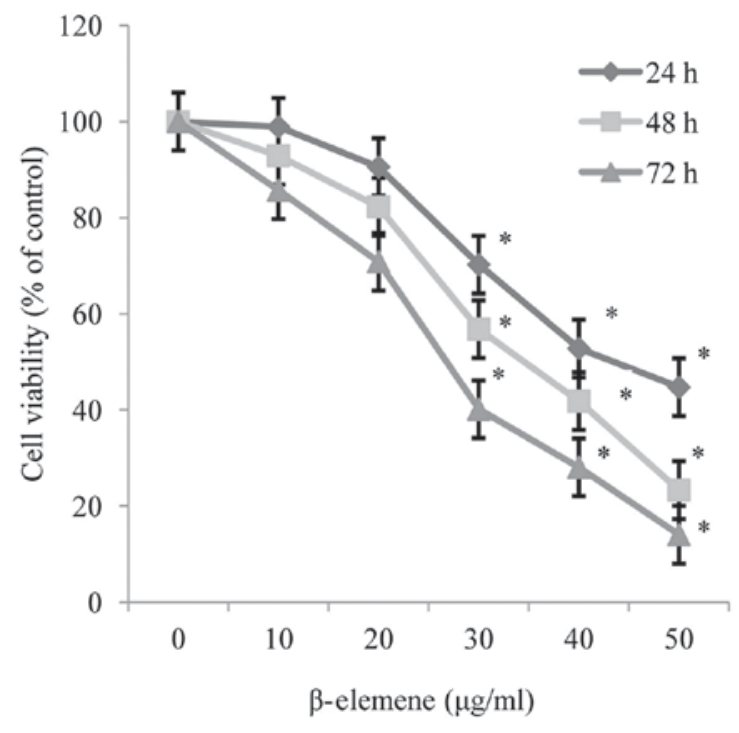

Figure 1. $\beta$-elemene inhibits the proliferation and survival of SiHa cells. Following treatment of SiHa cells with increasing doses of $\beta$-elemene $(0-50 \mu \mathrm{g} / \mathrm{ml})$ for 24,48 and $72 \mathrm{~h}$, the MTT assay was used to detect the proliferation and survival of SiHa cells. Each test was conducted in triplicate. Values presented represent the mean \pm standard deviation of the three independent experiments. "P<0.05 vs. $0 \mu \mathrm{g} / \mathrm{ml}$.

$\beta$-elemene induces apoptosis in SiHa cells. The results of the flow cytometry analysis revealed that treatment with increasing doses of $\beta$-elemene $(20,30$ and $40 \mu \mathrm{g} / \mathrm{ml})$, significantly increased the apoptotic rate of $\mathrm{SiHa}$ cells in a dose-dependent manner $(\mathrm{P}<0.05$; Fig. 3A). Furthermore, the levels of apoptosis-associated proteins were investigated, and it was demonstrated that the administration of $\beta$-elemene significantly upregulated the expression levels of p53 and Bax, and significantly downregulated the expression of $\mathrm{Bcl}-2$ ( $\mathrm{P}<0.05$; Fig. 3B).

$\beta$-elemene inhibits the invasion and migration of $\mathrm{SiHa}$ cells. The results of the Transwell assays demonstrated that $\beta$-elemene administration inhibited the motility and invasion of SiHa cells in a dose-dependent manner (Fig. 4A), the quantification results of which are presented in Fig. 4B $(\mathrm{P}<0.05)$. Furthermore, when $\mathrm{SiHa}$ cells were treated with $\beta$-elemene $(40 \mu \mathrm{g} / \mathrm{ml})$ for $72 \mathrm{~h}$, the invasive ability of the cells declined by $90 \%$. In addition, wound healing migration assays revealed that $\beta$-elemene administration inhibited the migration of SiHa cells in a dose-dependent manner, thus suggesting that $\beta$-elemene may significantly inhibit the migratory ability of SiHa cells (Fig. 4C). Furthermore, the expression levels of invasion-associated proteins were investigated, and it was revealed that $\beta$-elemene significantly downregulated the expression levels of MMP-2 and MMP-9 (P<0.05; Fig. 4D).

$\beta$-elemene suppresses the Wnt/ $\beta$-catenin signaling pathway. Following exposure of SiHa cells to $\beta$-elemene $(40 \mu \mathrm{g} / \mathrm{ml})$ for $48 \mathrm{~h}$, western blot analysis was performed in order to detect alterations in the expression levels of $\beta$-catenin, its target molecule TCF7, and their target protein, c-Myc. The results demonstrated that administration of $\beta$-elemene significantly suppressed the expression of $\beta$-catenin and its downstream target molecule TCF7 in SiHa cells, thus resulting in a reduced expression level of their target, c-Myc $(\mathrm{P}<0.05$; Fig. 5). 
A

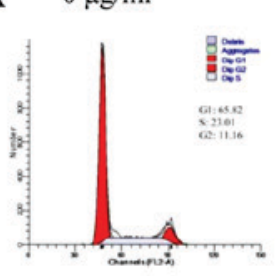

$30 \mu \mathrm{g} / \mathrm{ml}$
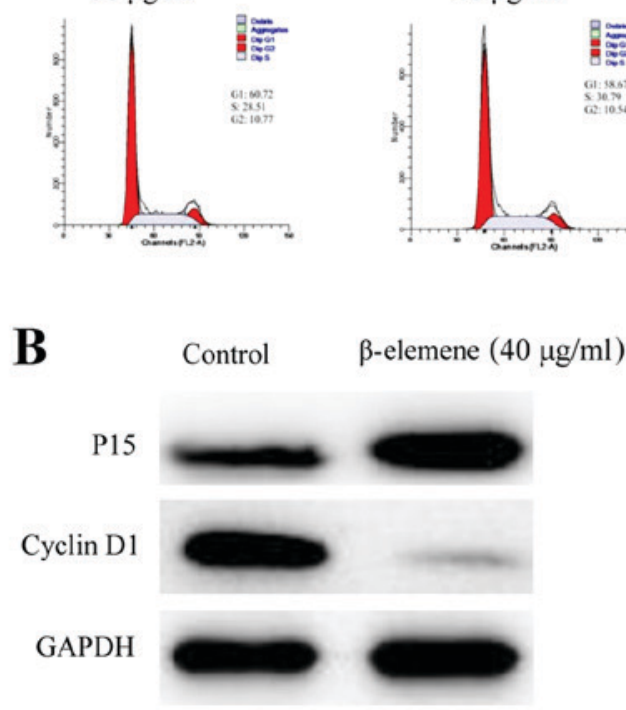

$20 \mu \mathrm{g} / \mathrm{ml}$

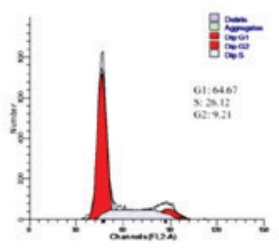

$40 \mu \mathrm{g} / \mathrm{ml}$
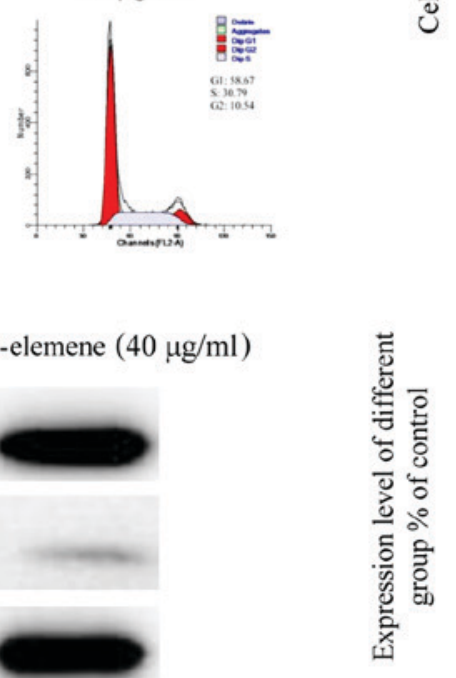
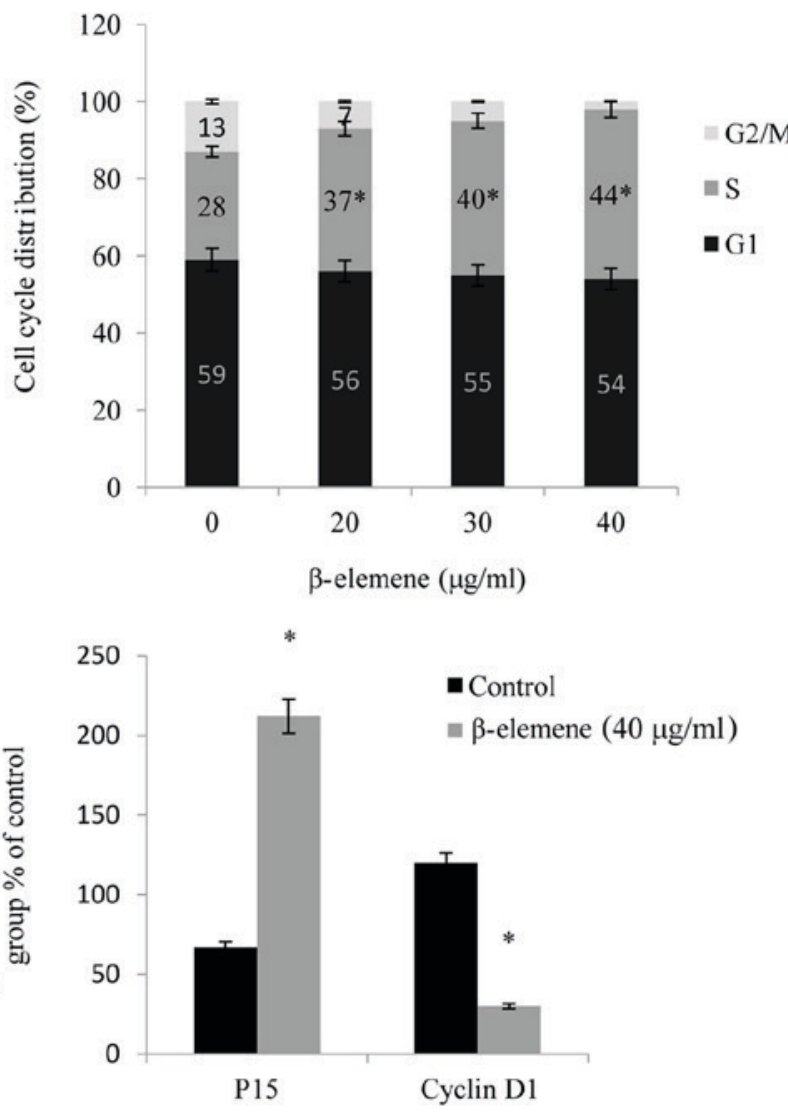

Figure 2. $\beta$-elemene induces cell cycle arrest in SiHa cells during G1. (A) Following treatmentof SiHa cells with increasing doses of $\beta$-elemene (0, 20, 30, and $40 \mu \mathrm{g} / \mathrm{ml}$ ) for $48 \mathrm{~h}$, flow cytometry was performed in order to investigate the influence of $\beta$-elemene on the progression of the cell cycle; ${ }^{*} \mathrm{P}<0.05 \mathrm{vs} .0 \mu \mathrm{g} / \mathrm{ml}$. (B) Western blot analysis of P15 and Cyclin D1 expression levels in SiHa cells. Each experiment was performed in triplicate. Values presented represent the mean \pm standard deviation of three independent experiments. " $\mathrm{P}<0.05$ vs. control. $\mathrm{P} 15$, Cyclin-dependent kinase inhibitor $2 \mathrm{~B}$.

\section{Discussion}

Curcuma zedoaria, the dried rhizome of Zingiberaceae plants, has previously been revealed to exhibit antitumor, antithrombotic and antibacterial effects, and has been used to treat many types of cancer in traditional Chinese medical practices (14). $\beta$-elemene, an extractable monomer from Curcuma zedoaria oil, has a wide antineoplastic spectrum, without toxic effects, and has been approved as an auxiliary treatment in China (8). Previous studies have revealed that the anticancer effects of $\beta$-elemene are predominantly due to the inhibition of tumor cell proliferation at a certain stage in the cell cycle, in addition to increased levels of apoptosis (7-9). However, the exact signaling pathways responsible for such therapeutic effects have not yet been determined. In the present study, the antineoplastic effects of $\beta$-elemene, in addition to the possible involvement of the $\mathrm{Wnt} / \beta$-catenin signaling pathway in cervical cancer cells, was investigated.

In the present study, the results of the MTT assay demonstrated that the administration of $\beta$-elemene resulted in significantly decreased viability of $\mathrm{SiHa}$ cells, in a dose and time-dependent manner. Furthermore, previous studies have revealed that treatment with $\beta$-elemene leads to inhibition of the proliferation of prostate cancer cells (15) and glioblastoma cells (16). In order to verify the ability of $\beta$-elemene to inhibit the cell cycle, flow cytometry was performed in order to determine the phases of the cell cycle, and the results demonstrated that treatment with $\beta$-elemene resulted in G1 phase cell cycle arrest in SiHa cells. Previous studies have demonstrated that $\beta$-elemene may inhibit cell proliferation via G0/G1 cell cycle arrest in human glioblastoma cells (17), and that $\beta$-elemene may arrest the cell cycle at the G2/M phase in ovarian carcinoma cells (18). The results of the present study differed from those of Zhu et al (18) with regards to the phase at which the cell cycle was arrested. Therefore, the results of the present study and those of previous studies suggest that the cell cycle stage at which $\beta$-elemene is able to cease cell proliferation varies across different cancer types.

The present study additionally demonstrated that treatment with $\beta$-elemene increased and decreased the expression levels of P15 and Cyclin D1, respectively. The P15 protein is able to induce cell cycle arrest at the G1/S phase via inhibition of the downstream Cyclin-dependent kinase 4/6, which further suppresses the activity of Cyclin D1 $(19,20)$. Therefore, it may be concluded that $\beta$-elemene inhibits the cell proliferation of SiHa cells via promotion of G1 phase cell cycle arrest. Furthermore, flow cytometry analysis revealed that the apoptotic rates of $\mathrm{SiHa}$ cells were significantly increased in groups treated with $\beta$-elemene in a dose-dependent manner. In addition, it was demonstrated that treatment with $\beta$-elemene markedly upregulated the expression levels of p53 and Bax, and markedly downregulated the expression level of Bcl-2. Furthermore, Bax and Bcl-2, two key regulators of mitochondria-mediated apoptosis, are integral members of the Bcl-2 
A $0 \mu \mathrm{g} / \mathrm{ml}$

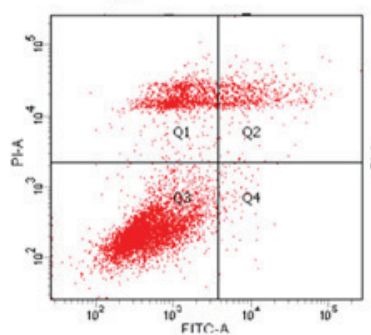

$30 \mu \mathrm{g} / \mathrm{ml}$

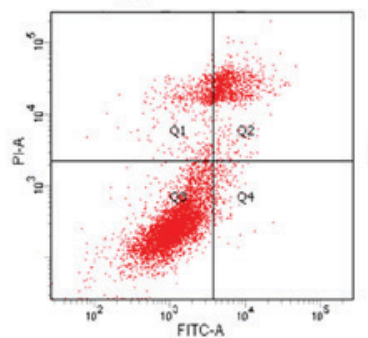

B

Control $\quad \beta$-elemene $(40 \mu \mathrm{g} / \mathrm{ml})$

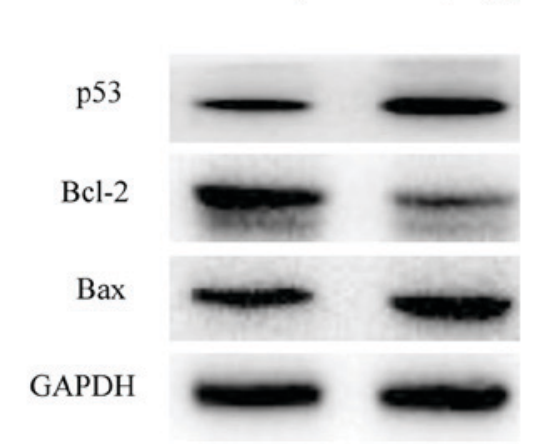

$20 \mu \mathrm{g} / \mathrm{ml}$

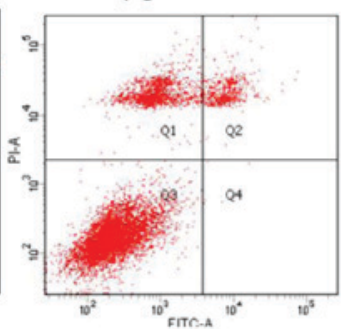

$40 \mu \mathrm{g} / \mathrm{ml}$

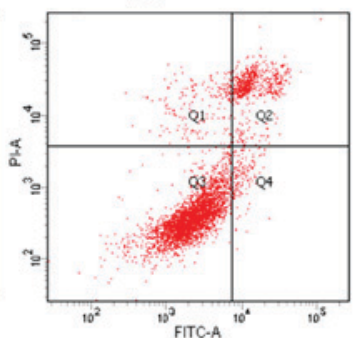

Figure 3. $\beta$-elemene induces apoptosis in SiHa cells. (A) Following treatment of SiHa cells with increasing doses of $\beta$-elemene $(0,20,30$, and $40 \mu \mathrm{g} / \mathrm{ml})$ for $48 \mathrm{~h}$, flow cytometry was performed in order to detect cellular apoptosis; ${ }^{*} \mathrm{P}<0.05 \mathrm{vs} .0 \mu \mathrm{g} / \mathrm{ml}$. (B) Western blot analysis of p53, Bax, and Bcl-2 expression levels in SiHa cells. Each experiment was performed in triplicate. Values presented represent the mean \pm standard deviation of three independent experiments. "P<0.05 vs. control. p53, cellular tumor antigen p53; Bax, apoptosis regulator BAX; Bcl-2, apoptosis regulator Bcl-2; PI, propidium iodide; FITC, fluorescein isothiocyanate.

protein family (21). The Bax/Bcl-2 ratio controls cell apoptosis: A higher Bax/Bcl-2 ratio results in caspase 3 activation and a subsequent increase in the rate of apoptosis (22). p53, a notable tumor suppressor protein, is able to promote cellular apoptosis via transcriptional activation of multiple genes, including those encoding the $\mathrm{Bcl}-2$ and caspase protein families. Furthermore, upregulation of p53 may further elevate the $\mathrm{Bax} / \mathrm{Bcl}-2$ ratio, thus inducing cellular apoptosis (23). Therefore, it was concluded that $\beta$-elemene induced apoptosis via upregulation of $\mathrm{p} 53$ expression and elevation of the $\mathrm{Bax} / \mathrm{Bcl}-2$ ratio in $\mathrm{SiHa}$ cells.

Transwell and wound-healing migration assays revealed that $\beta$-elemene inhibited the motility, invasion and migration of $\mathrm{SiHa}$ cells in a dose-dependent manner. In addition, the present study revealed that $\beta$-elemene was able to significantly downregulate the expression levels of MMP-2 and MMP-9. MMPs are extracellular matrix-degrading enzymes that are involved in the initiation of cell invasion and migration. MMP2 and MMP9, two important members of the MMP family, are able to degrade type V, Vll, and X collagen, in addition to gelatin and elastic fibers in the basement membrane
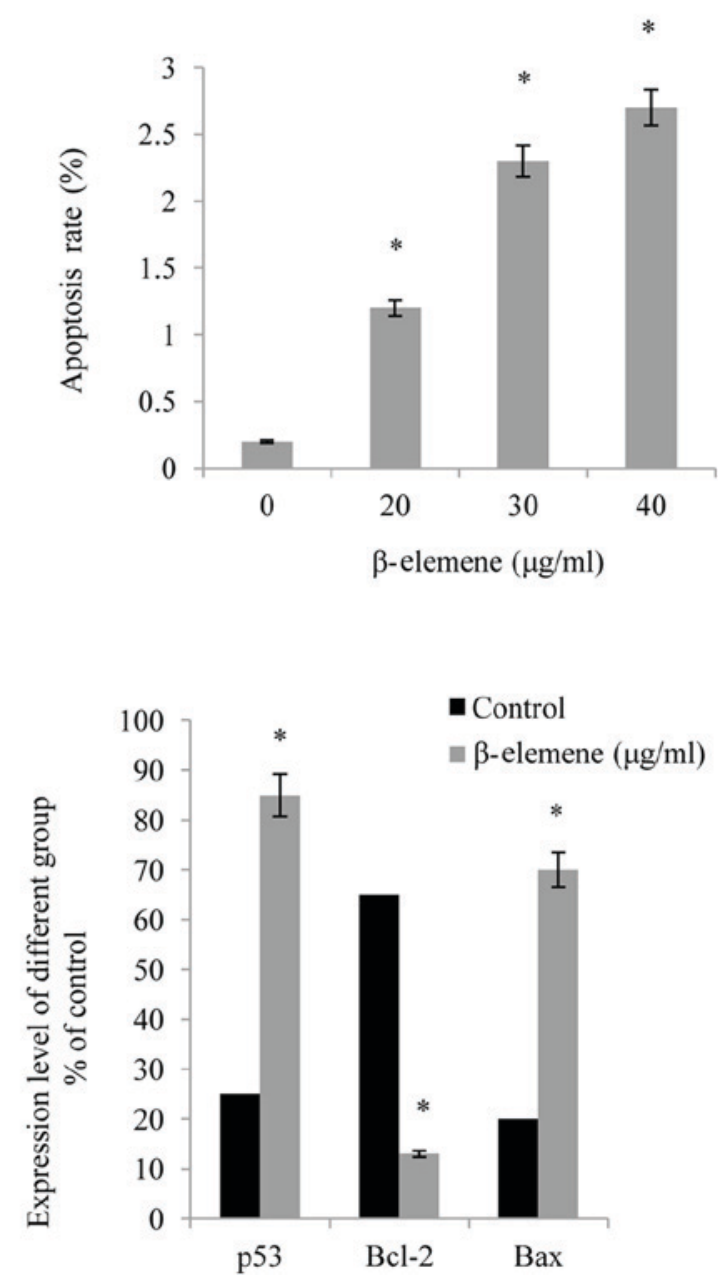

of the extracellular matrix, which may destroy the integrity of the basement membrane and further promote tumor cell invasion and migration through the basement membrane structure $(24,25)$. Therefore, it was concluded that $\beta$-elemene may inhibit cell invasion and migration via downregulation of MMP-2 and MMP-9 expression in SiHa cells.

The Wnt/ $\beta$-catenin signaling pathway consists of a series of proteins encoded by oncogenes and anti-oncogenes, and is notably implicated in embryonic development, intracellular transport and cellular apoptosis. In addition, abnormal activation of the $\mathrm{Wnt} / \beta$-catenin signaling pathway is associated with tumorigenesis, invasion and metastasis of various types of cancer $(12,26)$. During the activation of Wnt/ $\beta$-catenin signaling, $\beta$-catenin interacts with DNA via the TCF/lymphoid enhancer factor DNA binding protein and subsequently activates the expression of downstream target genes, encoding Cyclin D1 and c-Myc, which promote cell proliferation (27). In the present study, treatment with $\beta$-elemene downregulated the levels of $\beta$-catenin and its downstream target molecule TCF7, leading to downregulation of their target molecules, including Cyclin D1 and c-Myc; thus, this indicated that 
A

$\beta$-elemene

$20 \mu \mathrm{g} / \mathrm{ml}$

$30 \mu \mathrm{g} / \mathrm{ml}$

$40 \mu \mathrm{g} / \mathrm{ml}$

Cell motility
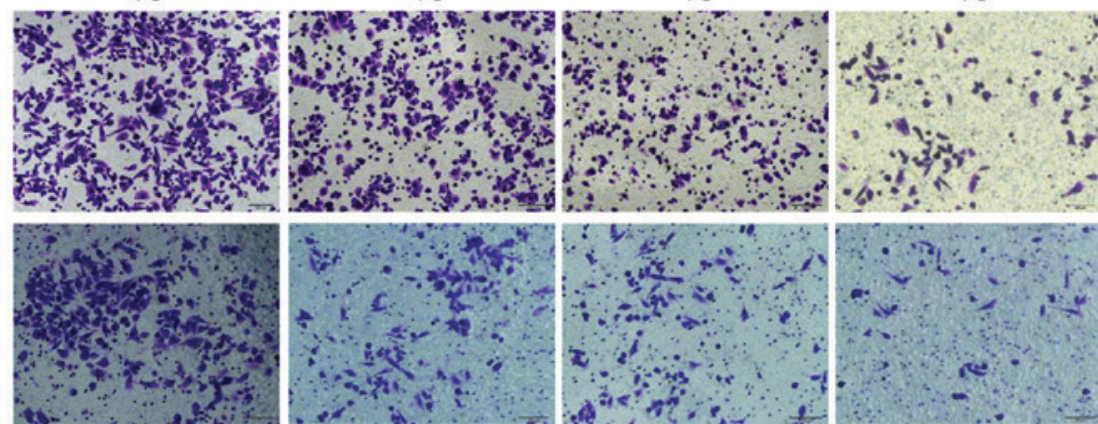

B
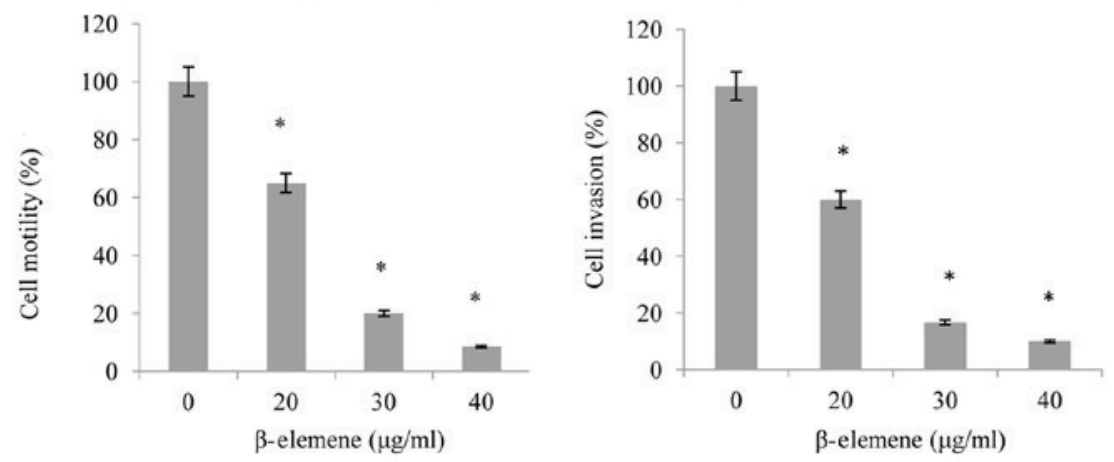

C $\quad \beta$-elemene $0 \mu \mathrm{g} / \mathrm{ml}$

$20 \mu \mathrm{g} / \mathrm{ml}$

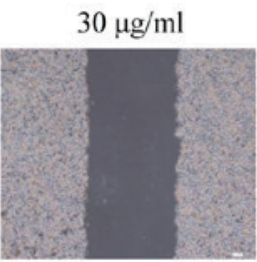

$40 \mu \mathrm{g} / \mathrm{ml}$

$0 \mathrm{~h}$
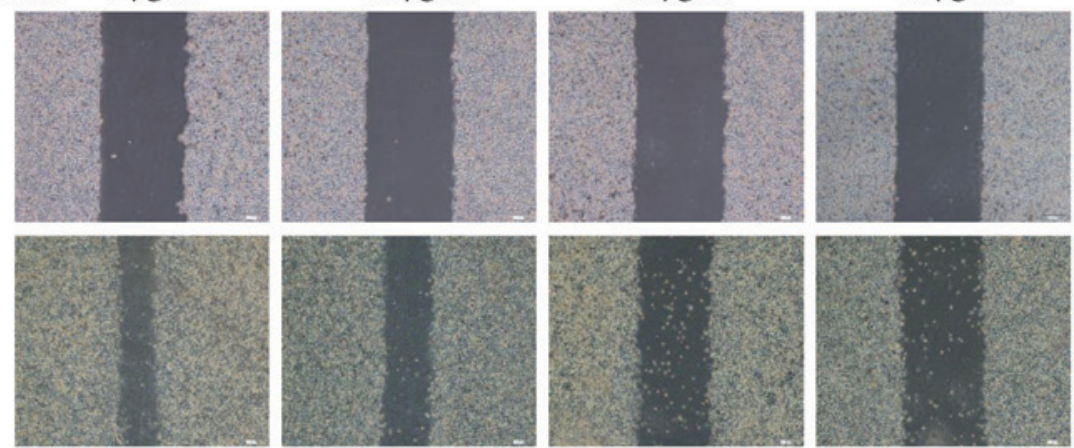

$48 \mathrm{~h}$

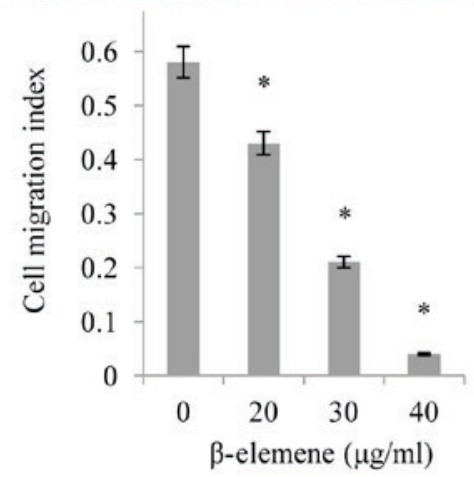

D
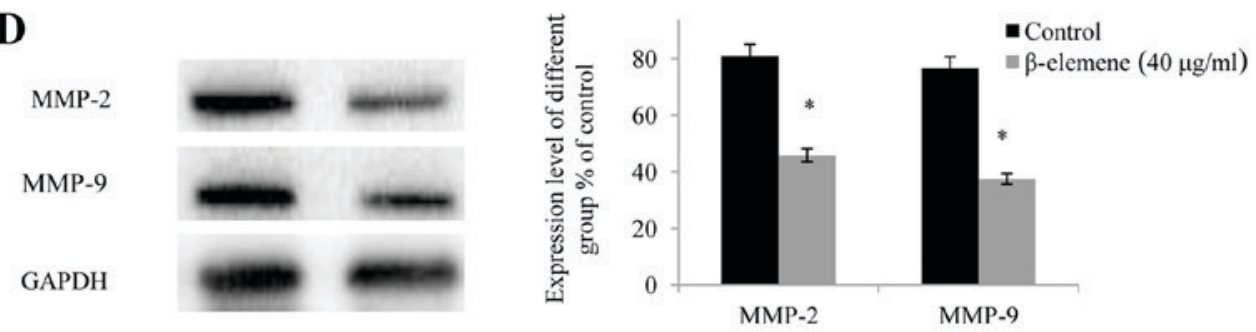

Figure 4. $\beta$-elemene inhibits the invasion and migration of SiHa cells. (A) Following treatmentof SiHa cells with increasing doses of $\beta$-elemene (0, 20, 30 and $40 \mu \mathrm{g} / \mathrm{ml}$ ) for 24 and $72 \mathrm{~h}$ time intervals, motility and invasion assayswere performed (magnification, x100). (B) Statistical analysis demonstrating the quantification of the number of invaded SiHa cellsfrom the motility and invasion assays; "P<0.05 vs. $0 \mu \mathrm{g} / \mathrm{ml}$. (C) The migration of SiHa cells was detected usinga woundhealing assay following treatment with $\beta$-elemene (magnification, $\mathrm{x} 200$ ), and cell migration distances were quantified; "P<0.05 vs. $0 \mu \mathrm{g} / \mathrm{ml}$. (D) Expression levels of MMP-2 and MMP-9 were detected by western blot analysis. Each experiment was performedin triplicate. Data presented represent the mean \pm standard deviation of three independent experiments. "P $<0.05$ vs. control. MMP-2, $72 \mathrm{kDa}$ type IV collagenase; MMP-9, matrix metalloproteinase-9. 


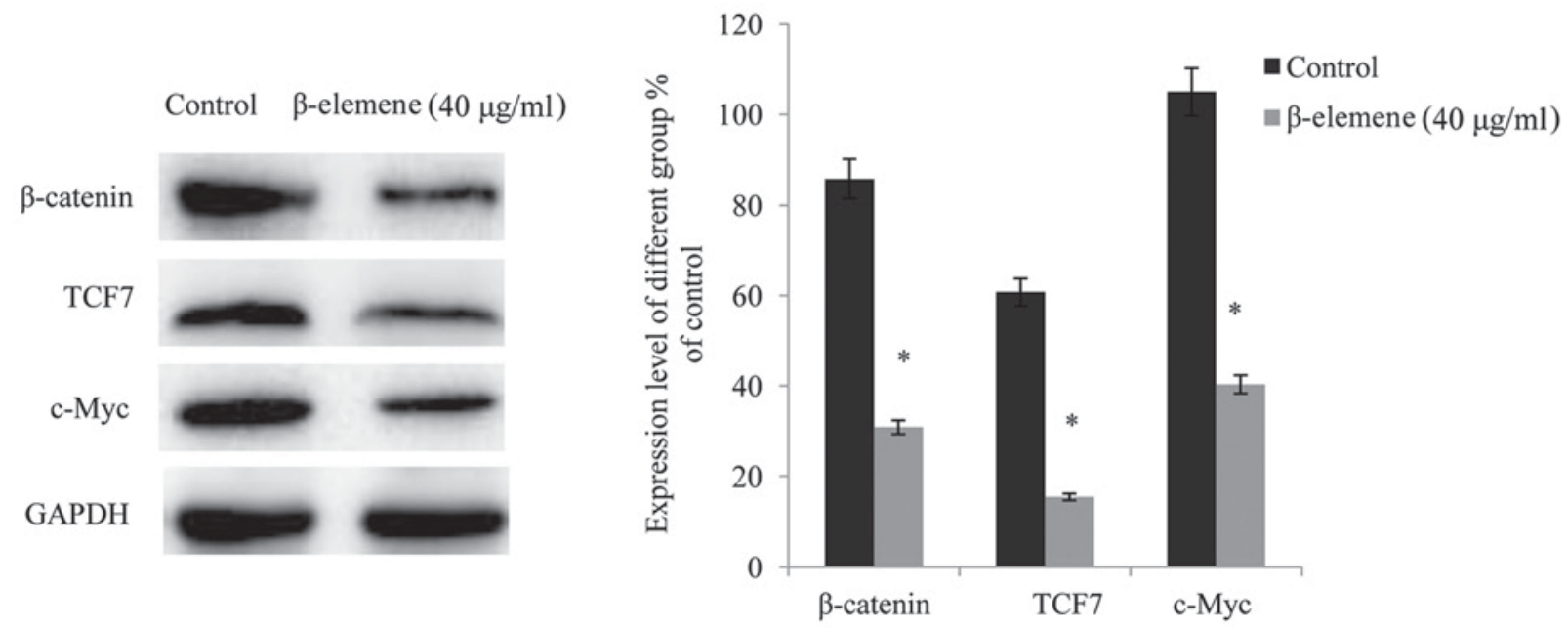

Figure 5. $\beta$-elemene suppresses the Wnt/ $\beta$-catenin signaling pathway. Expression levels of $\beta$-catenin, TCF7, and c-Myc were detected via western blot analysis. Each experiment was performed in triplicate. Values presented represent the mean \pm standard deviation of three independent experiments. "P $<0.05$ vs. control. TCF7, transcription factor 7; c-Myc, Myc proto-oncogene protein.

$\beta$-elemene inhibits SiHa cell proliferation via inhibition of the Wnt/ $\beta$-catenin pathway. Yao et al (10) demonstrated that $\beta$-elemene administration inhibited proliferation via the p38 mitogen-activated protein kinase-dependent pathway in glioblastoma cells. In addition, Liang et al (11) demonstrated that $\beta$-elemene inhibits cell viability via downregulation of the phosphatidylinositol 3-kinase/RAC- $\alpha$ serine/threonineprotein kinase/serine/threonine-protein kinase mTOR signaling pathway in human osteosarcoma cells. There are two pathways that control cellular apoptosis: The mitochondria-dependent pathway and the mitochondria-independent pathway. Upregulation of Bax in the mitochondria-dependent pathway may promote cytochrome release from the mitochondrial intermembrane space, which subsequently activates caspase 3 and consequently renders the cells susceptible to apoptosis. The mitochondria-independent pathway induces apoptosis via activation of a caspase cascade. Procaspase 8 triggers the downstream caspase effector and is responsible for the cleavage of caspase 8 , which activates caspase 3 and promotes cellular apoptosis (28). Cyclin D1 and survivin are able to induce the inhibition of caspase 3 expression. Wnt $/ \beta$-catenin signaling activates Bax, Cyclin D1 and surviving (29). The present study revealed that $\beta$-elemene increases the expression of Bax, and suppresses the expression of Cyclin D1; therefore, suggesting that $\beta$-elemene may induce cellular apoptosis via inhibition of the $\mathrm{Wnt} / \beta$-catenin signaling pathway.

p53 is a notable tumor suppressor gene, and the p53 protein is involved in cell cycle regulation, DNA repair and the induction of apoptosis. Previous studies have revealed that the intersection of the $\mathrm{p} 53$ and $\mathrm{Wnt} / \beta$-catenin pathways is TCF4, a member of the $\mathrm{Wnt} / \beta$-catenin signaling pathway that may be downregulated by p53 (30) and Dickkopf-1, and transcriptionally upregulated by $\mathrm{p} 53$, in order to further inhibit Wnt/ $\beta$-catenin activity (31). Further studies have revealed that $\mathrm{p} 53$ acts upstream of $\mathrm{Wnt} / \beta$-catenin in order to suppress the latter pathway (32). In the present study, it was demonstrated that $\beta$-elemene upregulates p53 expression levels, thus suggesting that $\beta$-elemene promotes $\mathrm{SiHa}$ cellular apoptosis via upregulation of p53 and subsequent inhibition of the Wnt $/ \beta$-catenin signaling pathway. Li et al (33) demonstrated that $\beta$-elemene induces apoptosis via Akt and extracellular-signal-regulated kinase signaling in order to deliver apoptotic signals to lung cancer cells. MMPs, highly conserved zinc ion-dependent proteolytic enzymes, are able to degrade the epithelial basement membrane or extracellular matrix and thus promote the invasion and metastasis of tumor cells. As targets of the Wnt $/ \beta$-catenin signaling pathway, MMP-2, MMP-7 and MMP-9 are involved in the process of inflammation regulation, tumorigenesis and tumor progression (34), in which MMP-7 activates both MMP-2 and MMP-9 in order to degrade collagen (35). Increased expression levels of $\beta$-catenin result in the upregulation of the expression levels of MMPs, which then act as contributors to tumor invasion and metastasis (34). The results of the present study suggest that $\beta$-elemene reduces the expression levels of $\beta$-catenin and its downstream target molecules, MMP-2 and MMP-9, further suggesting that $\beta$-elemene may inhibit cell invasion and migration via inhibition of the Wnt/ $\beta$-catenin signaling pathway in SiHa cells. Similarly, Zhang et al (36) demonstrated that $\beta$-elemene inhibited cell invasion and migration via downregulation of nuclear transcription factor expression mediated by mothers against decapentaplegic homolog 3 in MCF-7 cells.

In conclusion, the present study revealed that $\beta$-elemene inhibits the proliferation, invasion and migration of cervical cancer cells in vitro, and induces cellular apoptosis. Furthermore, it was demonstrated that $\beta$-elemene may exert its therapeutic effects via attenuation of the $\mathrm{Wnt} / \beta$-catenin signaling pathway. However, this remains to be investigated in a clinical setting. The results of the present study suggest that $\beta$-elemene may be a potential novel therapeutic agent for the treatment of cervical cancer.

\section{References}

1. Chen W, Zheng R, Zhang S, Zeng H, Xia C, Zuo T, Yang Z, Zou X and He J: Cancer incidence and mortality in China, 2013. Cancer Lett 401: 63-71, 2017. 
2. van Leeuwen CM, Oei AL, Chin KWTK, Crezee J, Bel A, Westermann AM, Buist MR, Franken NAP, Stalpers LJA and Kok HP: A short time interval between radiotherapy and hyperthermia reduces in-field recurrence and mortality in women with advanced cervical cancer. Radiat Oncol 12: 75, 2017.

3. Tewari KS, Sill MW, Long HJ III, Penson RT, Huang H, Ramondetta LM, Landrum LM, Oaknin A, Reid TJ, Leitao MM et al: Improved survival with bevacizumab in advanced cervical cancer. N Engl J Med 370: 734-743, 2014.

4. Wang H, Tao L, Ni T, Gu H, Jin F, Dai X, Feng J, Ding Y, Xiao W, Guo S, et al: Anticancer efficacy of the ethyl acetate extract from the traditional Chinese medicine herb Celastrus orbiculatus against human gastric cancer. J Ethnopharmacol 205: 147-157, 2017.

5. Kumar D, Basu S, Parija L, Rout D, Manna S, Dandapat J and Debata PR: Curcumin and Ellagic acid synergistically induce ROS generation, DNA damage, p53 accumulation and apoptosis in HeLa cervical carcinoma cells. Biomed Pharmacoth 81: 31-37, 2016.

6. Xu QY: The clinical value of local application of compound zedoary turmeric oil suppository for cervical human papilloma virus infection. Med Inform 2: 337-338, 2015 (In Chinese).

7. Zhang X, Zhang Y and Li Y: $\beta$-elemene decreases cell invasion by upregulating E-cadherin expression in MCF-7 human breast cancer cells. Oncol Rep 30: 745-750, 2013.

8. Bao F, Qiu J and Zhang H: Potential role of $\beta$-elemene on histone $\mathrm{H} 1$ in the $\mathrm{H} 22$ ascites hepatoma cell line. Mol Med Rep 6: 185-190, 2012.

9. Wang G, Li X, Huang F, Zhao J, Ding H, Cunningham C, Coad JE, Flynn DC, Reed E and Li QQ: Antitumor effect of beta-elemene in non-small-cell lung cancer cells is mediated via induction of cell cycle arrest and apoptotic cell death. Cell Mol Life Sci 62: 881-893, 2005.

10. Yao YQ, Ding X, Jia YC, Huang CX, Wang YZ and Xu YH: Anti-tumor effect of beta-elemene in glioblastoma cells depends on p38 MAPK activation. Cancer Lett 264: 127-134, 2008.

11. Liang D, Yang M, Guo B, Yang L, Cao J and Zhang X: HIF-1a induced by $\beta$-elemene protects human osteosarcoma cells from undergoing apoptosis. J Cancer Res Clin Oncol 138: 1865-1877, 2012.

12. Polakis P: Wnt signaling and cancer. Genes Dev 14: 1837-1851, 2000.

13. Chen C, Zhao M, Tian A, Zhang X, Yao Z and Ma X: Aberrant activation of $\mathrm{Wnt} / \beta$-catenin signaling drives proliferation of bone sarcoma cells. Oncotarget 6: 17570-17583,2015.

14. Lu JJ, Dang YY, Huang M, Xu WS, Chen XP and Wang YT: Anti-cancer properties of terpenoids isolated from Rhizoma Curcumae. J Ethnopharmacol 143: 406-411, 2012.

15. Li QQ, Wang G, Huang F, Banda M, Reed E: Antineoplastic effect of beta-elemene on prostate cancer cells and other types of solid tumor cells. J Pharm Pharmacol 62: 1018-1027, 2010

16. Zhao YS, Zhu TZ, Chen YW, Yao YQ, Wu CM, Wei ZQ, Wang W and $\mathrm{Xu}$ YH: $\beta$-elemene inhibits Hsp90/Raf-1 molecular complex inducing apoptosis of glioblastoma cells. J Neurooncol 107: 307-314, 2012 .

17. Li CL, Chang L, Guo L, Zhao D, Liu HB, Wang QS Zhang P, Du WZ, Liu X, Zhang HT, et al: $\beta$-elemene induces caspase-dependent apoptosis in human glioma cells in vitro through the upregulation of Bax and Fas/FasL and downregulation of Bcl-2. Asian Pac J Cancer Prev 15: 10407-10412, 2014.

18. Zhu T, Zhao Y, Zhang J, Li L, Zou L, Yao Y and Xu Y: $\beta$-elemene inhibits proliferation of human glioblastoma cells and causes cell-cycle G0/G1 arrest via mutually compensatory activation of MKK3 and MKK6. Int J Oncol 38: 419-426, 2011.

19. Jares P, Colomera D and Campo E: Genetic and molecular pathogenesis of mantle cell lymphoma: Perspectives for new targeted therapeutics. Nat Rev Cancer 7: 750-762, 2007.
20. Diehl JA: Cycling to cancer with cyclin D1. Cancer Biol Ther 1: 226-231, 2002.

21. Guo Q, Dong B, Nan F, Guan D and Zhang Y: 5-Aminolevulinic acid photodynamic therapy in human cervical cancer via the activation of microRNA-143 and suppression of the Bcl-2/Bax signaling pathway. Mol Med Rep 14: 544-550, 2016.

22. Adams JM and Cory S: The Bcl-2 apoptotic switch in cancer development and therapy. Oncogene 26: 1324-1337, 2007.

23. Levine AJ and Oren M: The first 30 years of p53: Growing ever more complex. Nat Rev Cancer 9: 749-758, 2009.

24. Yan Y, Liang H, Li T, Li M, Li R, Qin X and Li S: The MMP-1, MMP-2, and MMP-9 gene polymorphisms and susceptibilityto bladder cancer: A meta-analysis. Tumour Biol 35: 3047-3052, 2014.

25. Zhao H, Yuan X, Jiang J, Wang P, Sun X, Wang D and Zheng Q: Antimetastatic effects of licochalcone B on human bladder carcinoma T24 by inhibition of matrix metalloproteinases 9 and NF- $\kappa$ B activity. Basic Clin Pharmacol Toxicol 115: 527-533, 2014.

26. Hoffmeyer K, Raggioli A, Rudloff S, Anton R, Hierholzer A, Del Valle I, Hein K, Vogt R and Kemler R: Wnt/ $\beta$-catenin signaling regulates telomerase in stem cells and cancer cells. Science 336: 1549-1554, 2012.

27. Valenta T, Hausmann $\mathrm{G}$ and Basler K: The many faces and functions of $\beta$-catenin. EMBO J 31: 2714-2736, 2012.

28. Koff JL, Ramachandiran S and Bernal-Mizrachi L: A time to kill: Targeting apoptosis in cancer. Int J Mol Sci 16: 2942-2955, 2015.

29. Wu K, Ma L and Zhu J: miR-483-5p promotes growth, invasion and self-renewal of gastric cancer stem cells by Wnt/ $\beta$-catenin signaling. Mol Med Rep 14: 3421-3428, 2016.

30. Rother K, Johne C, Spiesbach K, Haugwitz U, Tschöp K, Wasner M, Klein-Hitpass L, Möröy T, Mössner J and Engeland K: Identification of Tcf- 4 as a transcriptional target of p53 signalling. Oncogene 23: 3376-3384, 2004.

31. Wang J, Shou J and Chen X: Dickkopf-1, an inhibitor of the Wnt signaling pathway, is induced by $\mathrm{p} 53$. Oncogene 30 : 1843-1848, 2000.

32. Kim NH, Kim HS, Kim NG, Lee I, Choi HS, Li XY, Kang SE, Cha SY, Ryu JK, Na JM, et al: p53 and microRNA-34 are suppressors of canonical Wnt signaling. Sci Signal 4: ra71, 2011.

33. Li L, Xu L, Qu X, Zhao M, Yu P, Kang J, Liu Y and Hu X: Cbl-regulated Akt and ERK signals are involved in $\beta$-elemeneinduced cell apoptosis in lung cancer cells. Mol Med Rep 4: 1243-1246, 2011

34. Wu B, Crampton SP and Hughes CC: Wnt signaling induces matrix metalloproteinase expression and regulates $\mathrm{T}$ cell transmigration. Immunity 26: 227-239, 2007.

35. Imai K, Yokohama Y, Nakanishi I, Ohuchi E, Fujii Y, Nakai N and Okada Y: Matrix metalloproteinase 7 (matrilysin) from human rectal carcinoma cells. Activation of the precursor, interaction with other matrix metalloproteinases and enzymic properties. J Biol Chem 270: 6691-6697, 1995.

36. Zhang X, Li Y, Zhang Y, Song J, Wang Q, Zheng L and Liu D: Beta-elemene blocks epithelial-mesenchymal transition in human breastcancer cell line MCF-7 through Smad3-mediated down-regulation of nuclear transcription factors. PLoS One 8: e58719, 2013

This work is licensed under a Creative Commons Attribution-NonCommercial-NoDerivatives 4.0 International (CC BY-NC-ND 4.0) License. 